\title{
Intermodal transportation as a quality improvement tool in tourism industry
}

\author{
Anzor Devadze ${ }^{1 *}$, Paata Chaganava ${ }^{2}$, Irakli Kordzaia ${ }^{3}$, and Lela Devadze ${ }^{2}$ \\ ${ }^{1}$ Batumi Shota Rustaveli State University, Tourism Department, 35/32 Ninoshvili/Rustaveli str., 6010 \\ Batumi, Georgia \\ ${ }^{2}$ Batumi Shota Rustaveli State University, 35/32 Ninoshvili/Rustaveli str., 6010 Batumi, Georgia \\ ${ }^{3}$ Batumi Shota Rustaveli State University, BSU Quality Assurance center, 35/32 Ninoshvili/Rustaveli \\ str., 6010 Batumi, Georgia
}

\begin{abstract}
The international tourism, with its developed transport infrastructure, transforms the earlier closed community into the open one, where the communications between the representatives of different countries become the everyday routine. Georgia has strategic geopolitical location on the conjunction of Europe and Asia and holds all the abilities to develop different types of passenger transportation and it enhances the further development of international tourism in the country. The authors examine the condition of country's transport infrastructure and organization of passenger transportation via different types of transport, aiming to carry out the directions of improving the quality of tourist's transport service and raising the competitiveness of tourism industry in Georgia, the authors proposed Intermodal Transportation Service Center as a tool of improving the quality of tourism services.
\end{abstract}

\section{Introduction}

Georgia with its Geopolitical location and natural, historical and cultural resources has practical unlimited resources to develop international tourism. While analyzing the tourism development issues it is very important to define its interconnection wit transport industry, keeping in mind that the development of tourism and transport is the interconnected and interdependent process. Related to the above mentioned it is rather actual the identification of impact of transport infrastructure on development of international tourism in Georgia, as the role and importance of tourism is acknowledged as most important factor of international tourism development. It is natural and logic, because tourism is relatively new social-economic phenomena and mostly is the result of transport development [1-5]. It became very important after the significant qualitative and quantitative changes in the tourism flow volumes, dynamics and structures at national and international levels.

The aim of the given research is to perform complex analyze of development of international tourism and problems of organization of passenger tourist transportation via all types of transport in Georgia and based on it carry out the methodic and practical recommendations to raise the effectiveness of organization of international tourism in the

\footnotetext{
${ }^{*}$ Corresponding Author: devadze.anzor@bsu.edu.ge
} 
country. To reach the goal of the research following objectives were set: analyze modern conditions of international tourism in Georgia; analyze modern conditions of organization of passenger transportation via different types of transport; identify problems in organization of passenger transportation; develop scientific-methodic recommendations for improving passenger transportation in Georgia aiming to raise the quality of transportation of international tourists via different types of passenger transport and competitiveness tourism industry of Georgia on the global market of tourism services.

\section{Methodology}

The theoretical and methodical base of the research are the publications of Georgian and foreign researchers in the sphere of economics, transport and tourism management, also the legal acts and normative-legal documents, regulating the legal and organizational issues of transport and tourism performance.

The informational base of the research are the materials of National Statistics Office of Georgia and its territorial bodies, Ministry of internal affairs and Ministry of Economy and Sustainable Development, also the information from Georgian National Tourism Administration and Tourism and Resorts Department of Autonomous Republic of Adjara. The methods of economic analysis, synthesis and analysis, and statistical methods were used during research. For the purposes of quantitative evaluations the official materials of National Statistics Office of Georgia were used to perform comparative analysis between analytical and statistical estimations. Practical importance of developed scientificmethodical and practical recommendations comprises the argumentation for systematic measures to improve the organization of performance of transport infrastructure of Georgia supporting the raising the effectiveness of development of international tourism in the country. Interesting publications on the topic, especially about the multimodal transportation and tourism are made by Efthymiou and Papatheodorou [6], Lohmann and Pierce [7], Yang, Li and Li [8], Chang and Shieh [9] and Darmawan and Chen [10].

\section{Tourism and transport in Georgia}

In the market economy the development of tourism business means the existence of recreational resources, suitable capital, technology and workforce. In contrast with other fields of economy, tourism resources of Georgia are much diversified and include natural and anthropogenic geo-systems, also the natural phenomena that have comfortable characteristics and consumer value for commercial activity to use for organization of leisure and recreation [1]. In the recent years (all the years except 2020, because of pandemic covid-19 that destructively influenced on international tourism, lowering its qualitative, quantitative and financial characteristics to the minimum. As a result, the article presents all the figures of international tourism development except 2020 year) Georgia faces sharp raising the number of international tourists and revenues from international tourism. in the year of 2019 the quantity of international tourists reached 9357964 persons (growth rate compared to the 2018 consisted of 7,8\%). Also, the revenues from international tourism exceed 3 268,7 million US dollars in 2019 (Table 1).

Table 1. Dynamics of international tourist arrivals and revenues 2011-2019 [3].

\begin{tabular}{|l|l|l|l|l|l|l|l|}
\hline \multirow{2}{*}{ Characteristic } & \multicolumn{7}{|c|}{ Years } \\
\cline { 2 - 8 } & $\mathbf{2 0 1 3}$ & $\mathbf{2 0 1 4}$ & $\mathbf{2 0 1 5}$ & $\mathbf{2 0 1 6}$ & $\mathbf{2 0 1 7}$ & $\mathbf{2 0 1 8}$ & $\mathbf{2 0 1 9}$ \\
\hline $\begin{array}{l}\text { International } \\
\text { Arrivals, thousand. }\end{array}$ & 5392,3 & 5515,6 & 5901,1 & 6350,8 & 7554,9 & 8679,5 & 9359,0 \\
\hline Revenues, mln USD & 1719,7 & 1787,1 & 1935,9 & 2097,4 & 2700,2 & 3222,0 & 3268,7 \\
\hline
\end{tabular}


The Table 2 below shows top-10 countries originate higher tourist arrivals in Georgia.

Table 2. Top 10 countries of international arrivals [2].

\begin{tabular}{|l|c|c|c|c|}
\hline \multirow{2}{*}{ Country } & \multicolumn{2}{|c|}{$\begin{array}{c}\text { International arrivals in Georgia, } \\
\text { Thousand }\end{array}$} & $\begin{array}{c}\text { Growth, } \\
\text { Thousand }\end{array}$ & Growth, \% \\
\cline { 2 - 3 } & $\mathbf{2 0 1 8}$ & $\mathbf{2 0 1 9}$ & & \\
\hline Azerbaijan & $1,424,610$ & $1,526,619$ & 102,009 & $7.2 \%$ \\
\hline Armenia & $1,268,886$ & $1,365,048$ & 96,162 & $7.6 \%$ \\
\hline Turkey & $1,268,886$ & $1,365,048$ & 96,162 & $5.3 \%$ \\
\hline Russia & $1,404,757$ & $1,471,558$ & 66,801 & $7.6 \%$ \\
\hline Ukraine & 158,160 & 189,210 & 31,050 & $19.6 \%$ \\
\hline Iran & 280,735 & 137,223 & $-143,512$ & $-51.1 \%$ \\
\hline Israel & 154,764 & 202,370 & 47,606 & $30.8 \%$ \\
\hline Kazakhstan & 51,489 & 77,856 & 26,367 & $51.2 \%$ \\
\hline Poland & 65,361 & 86,716 & 21,355 & $32.7 \%$ \\
\hline Germany & 61,422 & 85,251 & 23,829 & $38.8 \%$ \\
\hline
\end{tabular}

Positive tendency exists with the European union countries: for 2019 number of visits from European Union countries consisted 484 996, with the growth rate of 25,9\% related to previous year. Germany was the first country in the list with the addition of the number of foreign tourists - $+24,6$ thousand and Polland - +21,4 thousand [3].

Quantity of accommodation objects, registered in the database of Georgian National Tourism Administration, consists of 2575 units, and the number of beds - 94438. The leader is the region of Adjara - 26519 (28,1\%) beds, followed by Tbilisi - $23596(25 \%)$ beds. There are several international brand hotels operating in Tbilisi: Radisson Blu Iveria Hotel, Tbilisi Marriott, Courtyard Marriott, Sheraton, Holiday Inn, Citadines Apart Hotel, Best Western Tbilisi, ercure, Hotels and Preference, The Biltmore Hotel, Ibis Styles Tbilisi Center, Best estern Tbilisi City Centre, Ramada Encore, Moxy by Marriott. The list enriched with Wyndham Grand и Ibis Tbilisi Stadium in 2019. International brand hotels are functioning in the regions also. In particular, in 2019 Radisson BLU Tsinandali, Park Hotel Tsinandali and Holidey Inn opened in Kakheti, Best Western Gudauri in Gudauri. According to the figures of STR global the rate of occupation for Georgia consisted $56,7 \%$ in 2019 [2]. According to the Ministry of Internal Affairs of Georgia, international tourists cross the state border of the country by different means of transport (Figure 1).

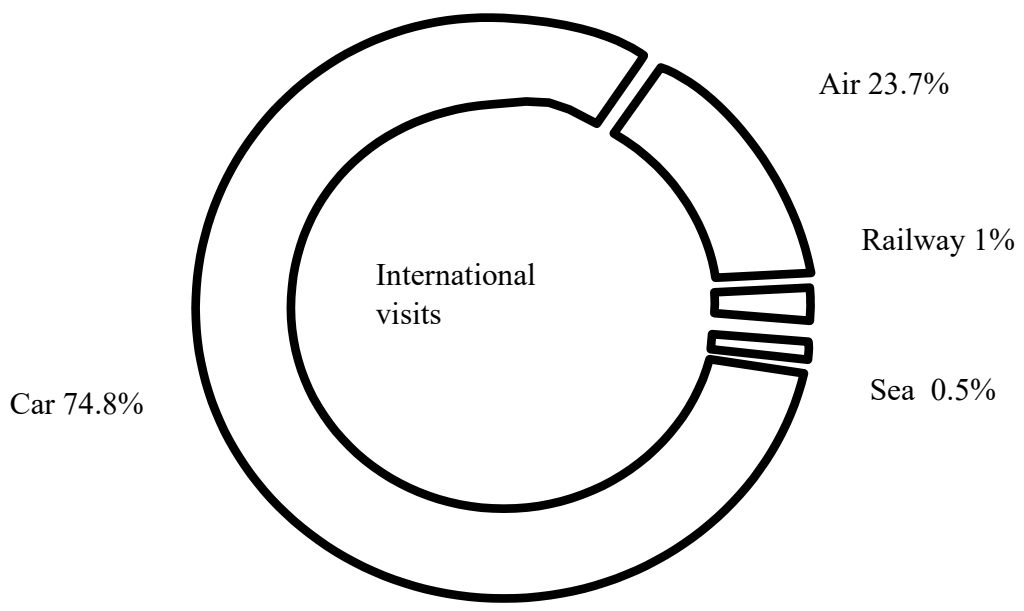

Fig. 1. Georgian border crossing by the different means of transport [4]. 
The most of crossings of international tourists assigned to the cars could be explained with the majority of travelers from neighboring countries: Armenia, Azerbaijan, Turkey, Iran etc., who prefers to travel with cars because of territorial closeness of Georgia and the accessibility of transport system. As for railway and sea transports' low rates, it is worth to mention that Georgia has the railway connection with Armenia and Azerbaijan only, also the sea passenger transportations take place from the sea ports of Batumi and Poti to the directions of Sochi (Russia) and Odessa (Ukraine), with the small amounts.

Georgia's flight market shows the considerable growth rate last years. In the prepandemic period there were 3 international and 2 internal airports working in Georgia, fully suitable to the standards of the International Civil Aviation Organization (ICAO). The international flight mostly consists of flights from and to Tbilisi airport. The management of Tbilisi and Batumi airports is performed by Turkish company TAV Airports Holding Co.

Air companies that worked in Georgia in Pre-pandemic period performed lowbudgetary flights with relative prices: Wizz Air, Air Arabia, Pegasus, FlyDubai, Pobeda Airlines, Air Baltic, Buta Airways, Salam Air, Flynas, Ukraine International Airlines, Skyup Airlines.

Processing ability of Tbilisi, Kutaisi and Batumi airports consists 6,1 million, 600 thousand and 600 thousand passengers per year, accordingly. After the completing the expanding of airports in Kutaisi and Batumi (planned at 2021) their processing ability will rise to 2,5 million and 1,4 million passengers per year, accordingly.

In 2019 nine new international air companies enter the Georgian market, including French Air France, Armenian Aircompany Armenia, Maltese Air Malta, Irish Ryan Air, and Uzbek Uzbekistan Airways. Charter flights are performed by Thailand's Thai AirAsia X, Latvian GetJet Airlines and Turkish Onur Air. The table 3 contains the dynamics of international flights and passengers served for 2012-2017 from the Georgian airports.

Table 3.Quantity of flights and passengers served for 2012-2017 [3].

\begin{tabular}{|l|c|c|c|c|c|c|c|}
\hline Years & $\mathbf{2 0 1 3}$ & $\mathbf{2 0 1 4}$ & $\mathbf{2 0 1 5}$ & $\mathbf{2 0 1 6}$ & $\mathbf{2 0 1 7}$ & $\mathbf{2 0 1 8}$ & $\mathbf{2 0 1 9}$ \\
\hline $\begin{array}{l}\text { Number of } \\
\text { flights }\end{array}$ & 13999 & 13576 & 13667 & 15318 & 20955 & 24606 & 24386 \\
\hline $\begin{array}{l}\text { Passengers } \\
\text { served, thsd. }\end{array}$ & 1833,8 & 2008,5 & 2261,1 & 2840,5 & 4074,0 & 5033,3 & 5200,5 \\
\hline
\end{tabular}

Transport is the key element of tourism product, in its part that the tourist consumes out of the tourist destination, on the way to it. While researching tourism, it is crucially important to define its interdependence with transport industry. The success on the tourist markets and adequate transport infrastructure are important conditions for development of tourist destination. By the other hand, demand on tourism is strong stimulus for accelerating the development of transport industry. Tourism depends on transport, its safety, speed and comfort; those are offered to the tourists during journey.

As it could be concluded from the analysis above, as tourism becomes massive phenomenon the range of the problems appears related to the transport services. One of the most important problems is the problem of imbalance of development of transport system of Georgia in total. It contains three elements.

Disproportion in the rates and scales of development of different types of transport. Best example for that - considerable low rates of sea transport development and high growth rates of automobile transport.

Insufficient development of existed transport infrastructure, that is shown in incomparability of the levels automobile roads to the level of automobile transport 
development and demand on automobile services, also in the existence of many problematic crossroads on the crossroads of different types of transport. Territorial inequality of development of transport infrastructure.

\section{Intermodal transportation}

Today the development of transport system becomes the necessary condition of implementation of innovation model of economic growth of Georgia and raising the service quality of passengers. Although the positive tendencies in the dynamics of several types of transport, the transport system in total doesn't respond to the existed demands and perspectives of country's development.

Each type of transport, performing passenger service, acts separately, according to its own interests, aiming to get maximum profit and do does not care about other types of transport. In sum the transport means are not used effective enough, the quality of passenger transportation services are low and their demand for transportation is not satisfied in sufficient manner.

If the role of transport infrastructure is not valued enough it affects negatively on the development of international tourism and quality of transport service of passengers and as a result, country could lose the image of attractive tourism country. To keep the level it is necessary to improve the existed legislation, perform the goal-oriented policy in the sphere of transport system.

Tourism and transport development is the interconnected and interdependent process. As it appears from the scientific literature the study of interconnections in the system "tourism-transport" the preference is given to the transport, because its role and meaning is acknowledged as an important factor of tourism development. It is natural and logic, as the tourism is relatively new social-economic phenomenon and in significant volume is the result of the transport development [5].

It is worth to mention that the majority of resorts in Georgia are in a significant distance from the major transport nodes of country, those are the cities of Tbilisi, Kutaisi and Batumi. , and the passengers voyaging to the resort zones face a number of problems when making the changes in the transport type to reach the final destination.

related to the above mention to improve the level of satisfaction of passengers, especially transit ones, in the transportation process there is a necessity of technical, technological, organizational and economic coordination of transportation process by different types of passenger transport, especially in key transport junctions of the country where the main mass of passengers, including tourists, are changing the transport types.

To meet the growing demands of tourists and passengers for transportation, it is desirable that the land transport agency, jointly with agencies of sea transport and civil aviation, under the management of Georgian ministry of economy and sustainable development to decide about creation joint web of service-center with the goal of elaborating and implementing the intermodal transport system on the main directions of passenger flows (Fig. 2).

Intermodal passenger transportation should be considered as the transportation of passengers, luggage and handbag from the point of origin to the final destination with the several types of transport by united transportation document, when the responsibility for total transportation process, including the connection in the conjunctions, takes particular operator or the third party operator (for example, tourist company).

Organization of intermodal passenger transportation represents the innovative and prospective directions of transport field development. This technology allows to combine the advantages of each type of transport and to make the transportation process most effective. 


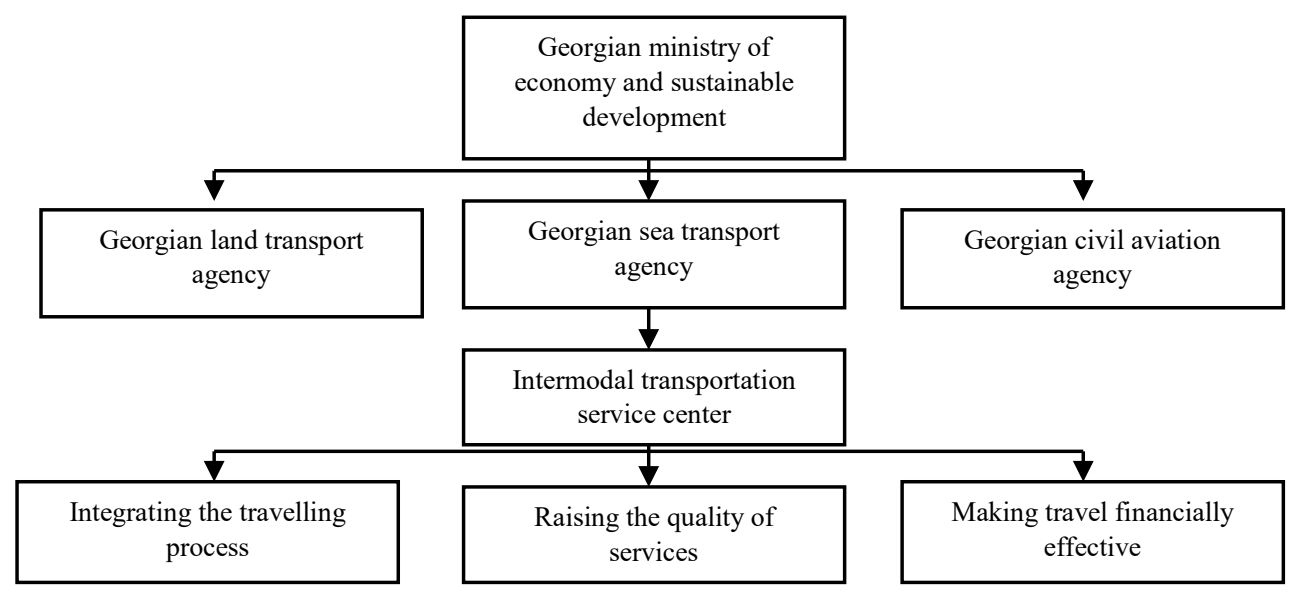

Fig. 2. Intermodal transportation service center.

In relation with the specifics of technology of organization of this type of passenger transportation, also taking into account the different requirements of passengers according to the types of transportation it is mostly preferable to use intermodal technology for the transportation of long haul passengers using such a types of transport as air, rail, car and sea transport. The key condition for such a technology is the presence of responsible person for successful change in conjunctions that means the solution of problems and avoiding of financial lost for passenger those could appear at the time of unsuccessful change, and the responsible person takes responsibility to solve the unforeseen situation and take the passenger to the final destination.

During the introducing the intermodal transportation it is desirable to draw the key principles to implement:

- High level of integration operators managing different types of transport;

- Information assurance of passengers during all the time of transportation "from door to door";

- Unified system;

- Interaction of the transport types on the basis of united rules and requirements;

- Maximization of use of advantages of each transport type participant in intermodal transportation;

- United informational area;

- Value benefit for the passenger compared to the total value of separate transportation along the route.

Unification of above mentioned transport agencies into one web of service-center and establishing the suitable communications between them allows creating different tourist products according to the formulae "train + bus + . .."; "train + bus + hotel"; "train + bus + excursion"; "train + bus + football event"; "airplane + bus + sanatorium" "airplane + bus + mountain resort" etc. advertisement of the created tourist products and their development could be performed by above mentioned service-center, tourist firms and agencies, in the close collaboration with sea, rail, car and air transport companies (Fig. 3).

The service-center could allow the improvement of the interaction of different transport companies that means improvement of quality of transportation of transit passengers on the basis of the elaboration of common transport schemas with agreed schedules of intercity or suburb buses with sea, rail or air transport at the transport junctions.

The specific attention should be paid to the some problematic issues, which appear during the service performed by tourist firms and transport organizations. 


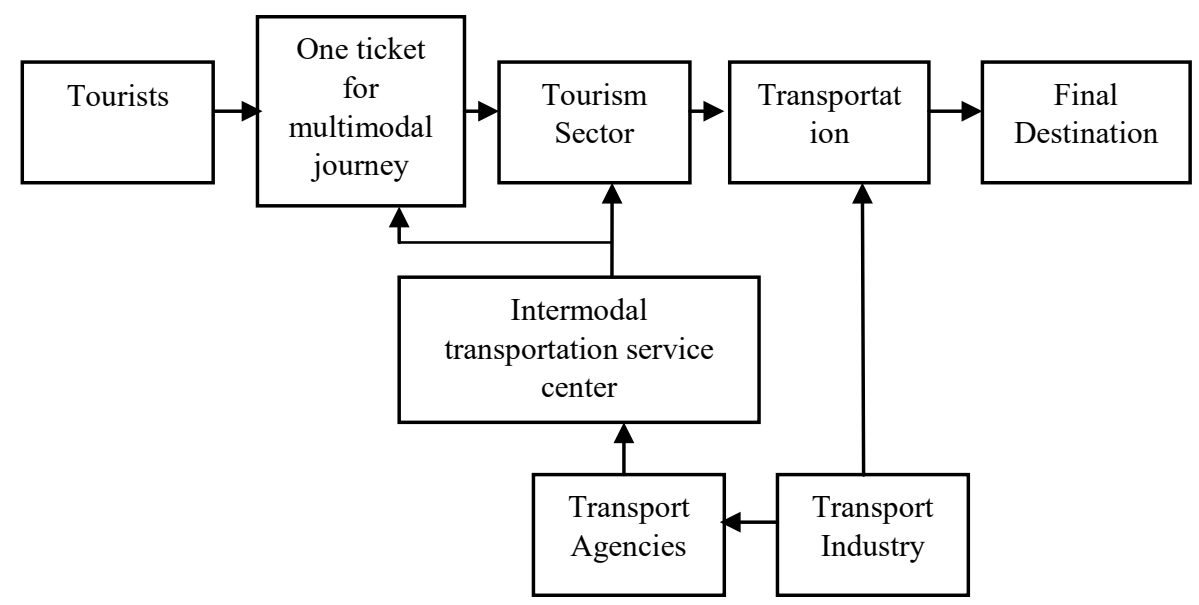

Fig. 3. Role of Intermodal transportation service center in the tourism services.

The most important is that the transport costs contain the $40-50 \%$ of total expenditures of tourist services. Such a ratio of prices blocks the tourist firm's ability to perform the elastic price policy during implementation of full pack of tourist service. In given conditions the non-price methods of competition are put on front and contain attracting consumers by improving quality of services offered alongside with additional services.

\section{Conclusion}

The problem of improving the effectiveness of transport infrastructure is one of the most important for the future development of country's international tourism. It should be considered on the comprehensive basis, taking into account the regional conditions of functioning of all transport types, reflecting the territorial and other specifics of their exploitation. Improvement of the quality of services for transit tourists should be ensured on the basis of elaboration of high-effective forms of transportation process organization by improving the interaction of different transport companies.

\section{References}

1. Devadze, A. (2012). Tourism in Georgia: existed situation, problems, perspectives. Publ.House Kabadoni.

2. Georgian National Tourism Administration. (2020). Account of 2019. Tbilisi.

3. Georgian National Tourism Administration. (2020). Operative Data of 2019. Tbilisi.

4. Ministry of internal affairs of Georgia. (2018). Operative Data of 2017. Tbilisi.

5. Meladze, M. (2008). The specifics of craft of tourist product in Georgia. Publ. House Kabadoni.

6. Efthymiou, M., Papatheodorou, A. (2015).Intermodal passenger transportation and destination competitiveness in Greece. Anatolia. 26:3, 459-471 https://doi.org/10.1080/13032917.2015.1012171

7. Lohmann, G., Pearce D.G. (2010). Conceptualizing and operationalizing nodal tourism functions. Journal of Transport Geography, 18, 266-275.

8. Yang Y., Li D., Li X. (2019). Public transport connectivity and intercity tourist flows. Journal of travel research, 58(1). 25-41. 
9. Chang, P., Shieh, H. (2016). Seamless service strategies for passenger transportation in Taiwan. International Journal of Business and social science, 7, 136-148.

10. Darmawan, V.E.B., Chen, Y.W. (2020). Implementation of connection scan algorithm in tourism intermodal transportation journey planner: a case study. Jurnal system dan manajemen industry, 4, 129-136. 